manufactured before January 1, 1949, and is marked accordingly. Apparatus manufactured after that date, and any apparatus not marked with the date of manufacture, will be acceptable only if its errors fall within the specified limits when the values are expressed in absolute units.

\section{Unit of Light}

The National Physical Laboratory will, on and after January 1, 1948, express all photometric values in terms of units based on the 'new candle'. This unit of luminous intensity is of such a magnitude that the brightness of a full (or cavity) radiator (black body) at the temperature of solidification of platinum is 60 'new candles' per square centimetre. The 'new lumen' is the luminous flux radiated within unit solid angle by a uniform source having a luminous intensity of one 'new candle'. The new unit of illumination will be one 'new lumen' per unit area. One 'new lumen' per sq. ft. will also be called one 'new footcandle', and one 'now lumen' per sq. metre one 'new lux'. The new unit of brightness will be one 'new candle' per unit area, and, alternatively, one 'new foot-lambert'. The latter unit is defined as the brightness of a perfectly diffusing surface of 100 per cent reflexion factor when its illumination is one 'new lumen' per square foot.

When differences of colour are involved in the determination of any magnitude in terms of the above units, the evaluation will be in accordance with that which would be obtained by an observer having the relative luminosity curve (the curve connecting eye sensitivity with wave-length) adopted by the International Commission on Illumination in 1924 and later by the International Committee of Weights and Measures.

The differences between the new units and those in use hitherto are small. The present units, based. on the 'international candle', were introduced on April 1, 1909 , in Great Britain, France and the United States of America, and were adopted in 1921 by the International Commission on Illumination. Nevertheless, Germany and some Central European countries continued to use units based on the Hefner candle (about 0.9 international candle). The international candle was not based on any primary standard; it was derived from the units defined in terms of the old flame standards, and was maintained by means of carbon and tungsten filament electric lamps. Further, the values of the unit at different colour temperatures did not exactly agree, when compared on the basis of the international relative luminosity curve adopted in 1924.

The magnitude of the new unit has been so chosen that it will introduce only very small changes (less than 0.5 per cent) in the values of luminous intensity assigned to lamps operating at a colour temperature of about $2,360^{\circ} \mathrm{K}$. For lamps at considerably higher colour temperatures, for example, ordinary gas-filled electric lamps at normal efficiencies, the values expressed in terms of the 'new candle' will be several per cent lower than those expressed in international candles. At the colour temperature of the primary standard $\left(2,046^{\circ} \mathrm{K}\right.$.), values in terms of the 'new candle' are about $1 \cdot 7$ per cent higher than those in terms of the international candle.

On account of this alteration in the basis on which sources of light of different colours are compared, it is impossible to give a factor for converting values in international candles to values in 'new candles'.

\section{U.S. NATIONAL ACADEMY OF SCIENCES}

\author{
Elections and Awards
}

A $\mathrm{T}$ the annual meeting of the U.S. National. Academy of Sciences held in Washington during April 28-30, the following officers, members, and foreign associates were elected :

President (July 1, 1947-June 30, 1951) : Alfred N. Richards, vice-president in charge of medical affairs, University of Pennsylvania (in succession to Dr. Frank B. Jewett).

Home Secretary (re-elected for a further term of four years ending June 30, 1951): F. E. Wright, Carnegie Institution of Washington, Washington, D.C.

Members of the Council of the Academy (for a threeyear term onding June 30, 1950): W. Albert Noyes, jun., chairman, Department of Chemistry, University of Rochester, Rochester, N.Y.; and Donald D. Van Slyke, chief chemist, Hospital of the Rockefeller Institute for Medical Research, Now York City.

Members : Luis W. Alvarez, professor of physics, University of California, Berkeley, California ; Robert F. Bacher, U.S. Atomic Energy Commission, Washingtion, D.C. ; Paul D. Bartlett, professor of chemistry, Harvard University, Cambridge, Mass.; Jacob Bjerknes, professor of physics, University of California at Los Angeles, California; Francis G. Blake, dean of Yale University School of Medicine, Now Haven, Conn.; R. Alexander Brink, chairman of the Department of Genetics, University of Wisconsin, Madison, Wisconsin ; Ralph W. Chaney, professor of paleobotany and curator of paleobotany, Museum of Paleobotany, University of California, Berkeley, California; Arthur C. Cope, professor in charge of the Department of Chemistry, Massachusetts Institute of Technology, Cambridge, Massachusetts ; Farrington Daniels, professor of physical chemistry, University of Wisconsin, Madison, Wisconsin ; Arnold Gesell, director, Clinic of Child Development, Yale University School of Medicine, New Haven, Connecticut; James Gilluly, professor of geology, University of California at Los Angeles, California; R. B. Goldschmidt, professor of zoology, University of California, Berkeley, California; Samuel A. Goudsmit, professor of physics, Northwestern University, Evanston, Illinois; C. H. Herty, jun., research engineer and assistant to vice-president, Bethlehem Steel Company, Bethlehem, Pennsylvania ; Frederick L. Hisaw, professor of zoology, Harvard University, Cambridge, Massachusetts; Wolfgang Köhler, professor of psychology, Swarthmore College, Pennsylvania; L. G. Longsworth, associate member, Rockefeller Institute for Medical Research, New York City ; Edwin M. McMillan, professor of physics, University of California, Berkeley, California ; Walter J. Meek, acting dean, Medical School, University of Wisconsin, Madison, Wisconsin; J. L. Oncley, director, Ultracentrifuge Laboratory, Harvard University Medical School, Boston, Massachusetts; Lars Onsager, professor of chemistry, Yale University, New Haven, Conn.; John P. Peters, professor of medicine, Yale University, New Haven, Conn.; Paul A. Smith, professor of mathematics, Columbia University, New York City ; C. Richard Soderberg, professor of applied mechanics, Massachusetts Institute of Technology, Cambridge, Massachusetts ; Paul Weiss, professor of zoology, University of 
Chicago, Chicago, Illinois ; F. W. Went, professor of plant pathology, California Institute of Technology, Pasadena, California; Robert E. Wilson, chairman of Board of Directors, Standard Oil Company of Indiana, Chicago, Illinois ; E. Bright Wilson, jun., professor of chemistry, Harvard University, Cambridge, Massachusetts.

Foreign Associates : P. A. Alexandroff, professor of mathematics, University of Moscow ; K. LinderstrømLang, head of the Chemical Division, Carlsberg Laboratory, Copenhagen ; J. N. Brønsted, professor and director of the Institute for Physical Chemistry, Copenhagen; Björn Helland-Hansen, director of the Geophysical Institute, Bergen; F. C. Bartlett, director of the Psychological Laboratory and professor of experimental psychology, University of Cambridge.

\section{Medal Awards}

John J. Carty Medal. The John J. Carty Gold Medal and Award for 1947 was presented to Dr. Ross G. Harrison, professor emeritus, Osborn Zoo. logical Laboratory, Yale University, New Haven, Connecticut, for the discovery that tissue cells can be grown outside the animal body, and by the use of this discovery demonstrating the manner of growth of nerve fibres, a fundamental contribution to scientific medicine and biology; for long and distinguished service as investigator, teacher, and counsellor of students; and for statesmanlike direction of the National Research Council during a period in which it played a vital part in the defence of the United States. As a young man at Johns Hopkins he obtained striking experimental results while engaged in the study of the development of the nervous system. Here he first used the method of isolation of embryonic tissues in culture media and gave an ocular demonstration that the nerve fibre grows out from a single cell without the participation of accessory cells. This led to the procedure known as tissue culture, which has since been widely used in the study of the differentiation, growth and behaviour of normal and tumour cells under various conditions outside the body. After retirement from active university work in 1938 Dr. Harrison became chairman of the National Research Council, which post he held until June 30, 1946. The Council has grown in esteem under his leadership, not as an organisational instrument merely, but also as a place where men gather in friendly association to advance common interests.

Provision for the Carty Medal and Award was made by the American Telephone and Telegraph Company in honour of the late John J. Carty, a member of the Academy, as a token of esteem on the occasion of his retirement from active service. Under the terms of the deed of establishment, the award can be made not more often than once in two years. It can be conferred on anyone who in the judgment of the National Academy of Sciences has made noteworthy contributions to the advancement of fundamental or applied science in any field.

Daniel Giraud Elliot Medal. The Daniel Giraud Elliot Medal for 1945 has been awarded to Dr. Sewall Wright, Department of Zoology, University of Chicago, for his fundamental work dealing with the genetics of evolutionary processes; a programmebased on work over a long period, including his paper, "The Differential Equation of the Distribution of Gene Frequencies" (Proc. Nat. Acad. Sci., 31, No. 12 ; 1945).

Public Welfare Medal. The Public Welfare Medal of the Marcellus Hartley Fund for 1947 has been awarded to Dr. Karl T. Compton, president of Massachusetts Institute of Technology, Cambridge, Massachusetts, for eminence in the application of science to the public welfare, in recognition of his distinguished contributions of an original character to the science of physics, of his long and valuable career in the field of education and of university administration, and of his great service to the Government of the United States both before and during the War as a member of the National Defense Research Committee and as director of the Office of Field Service of the Office of Scientific Research and Development. "It is the purpose of the Public Welfare Medal to mark the appreciation of the National Academy for eminent services to the public, performed without a view to great monetary gains and by methods which in the opinion of the Academy are truly scientific."

Agassiz Medal. The Agassiz Medal of the Murray Fund for the year 1947 was awarded to Felix Andries Vening Meinesz, professor of geodesy and geophysics in the University of Utrecht and president of the Netherlands Geodetic Commission.

Because of the instability of the water-soaked ground in the Netherlands it was not possible to make accurate measurements of gravity there with the older types of instruments. In order to overcome the difficulty Vening Meinesz designed his multiplependulum apparatus by which the desired measurements could be made on unstable ground. Prior to this invention attempts had been made to measure gravity at sea, notably by Hecker, but the results had errors ten times greater than was permissible in measurements made on land. As Vening Meinesz's apparatus could be used on a submarine it made possible gravimetric surveys of the different oceans. In 1923, with the help of the Netherlands navy, Vening Meinesz made his first long voyage, going from a home port to the Netherlands East Indies by way of Suez. In subsequent years he made many voyages in the Atlantic, Pacific, and Indian oceans, paying particular attention to the Mid-Atlantic Ridge and the West and East Indian island arcs. By the beginning of the Second World War, 844 observations had been made on Netherlands submarines, and many observations had been made on submarines of other countries. Among the interesting results of the gravimetric surveys was the discovery of strips of ocean bottom with negative anomalies, which in both the Last and West Indies coincide with the seismic belts and the deep narrow troughs of those regions. The Mid-Atlantic Ridge is fundamentally different from the great island ares in that in it there are no strips with negative anomalies. Two other generalizations are that fields of positive anomalies usually coincide with deep basins, and that the anomaly increases positively in going from shallow to deep water off both continental and island coasts.

Besides having made the measurements indicated above and having studied their distribution with reference to relief, seismic, and volcanic features, Vening Meinesz has proposed explanations of the processes operative in the formation of the troughs with the negative anomalies and the faults and folds in adjacent areas, a hypothesis for the explanation of the origin of the continents and ocean basins, and a hypothetical explanation of a postulated rotation of the earth's crust over deeper-seated material. The value of these unique researches in the study of the physical features of the ocean bottom and adjacent land areas is beyond estimate. 